\title{
STUDIES ON THE DENSITY OF NATURALLY AND ARTIFICIALLY FORMED FRESH-WATER ICE
}

\author{
By B. H:son Ager* \\ (Statens Skogsforskningsinstitut, Stockholm)
}

\begin{abstract}
Observations were made on the density of naturally and artificially formed lake and river ice. The effect of initial snow density, size and shape of snow crystals, rate of water spread and rate of freezing on the density of snow-ice obtained was studied in the laboratory and is presented in graphical form. The observations indicate that snow-ice formed under natural conditions will probably have a density between 0.85 and $0.90 \mathrm{~g} . / \mathrm{cm} .^{3}$. The classification of snow-ice is discussed briefly.
\end{abstract}

RÉsumé. On a effectué des observations de la densité de glace de rivière et de glace de lac formées naturellement et artificiellement. La densité de la neige, les dimensions et la forme de ses cristaux, la vitesse de pénétration de l'eau et sa congélation ont un effet sur la densité de la glace obtenue en saturant la neige d'eau; cet effet a été étudié en laboratoire et est présenté sous forme de graphiques. Les observations montrent que la densité de cette espèce de glace, obtenue dans des conditions normales, oscille probablement entre 0,85 et $0,90 \mathrm{~g} / \mathrm{cm}^{3}$. La classification de cette glace est discutée brièvement.

Zusammenfassung. Über die Dichte natürlichen und künstlichen See- und Flusseises wurden Beobachtungen angestellt. Der Einfluss der ursprünglichen Schneedichte, der Grösse und Form der Schneekristalle, der Menge des zugeführten Wassers und des Grades der Abkühlung auf die Dichte von Eis, das durch Einfrieren von wassergesättigtem Schnee entsteht ("Schnee-Eis"), wurde im Laboratorium untersucht und in Diagrammen dargestellt. Die Beobachtungen zeigen, dass Schnee-Eis, das sich unter natürlichen Bedingungen bildet, gewöhnlich eine Dichte zwischen 0,85 und $0,90 \mathrm{~g} / \mathrm{cm}^{3}$ besitzt. Die Klassifizierung von Schnee-
Eis wird kurz diskutiert.

\section{INTRODUCTION}

It is common practice in the logging industry in Scandinavia, Canada and other countries to place wood in temporary storage on the ice cover of rivers and lakes. These "landings", as they are called, must support considerable weight and it is often necessary to strengthen them by flooding the ice surface so that it reaches the required thickness in the shortest possible time. It is normal practice also to compact the snow on the cover to reduce its thermal resistance or make it more suitable for flooding. Increasing the thickness of the ice cover by either natural or artificial flooding of the upper surface, however, usually produces ice with a density lower than that of ice formed by natural growth at the ice-water interface. There is little published information available on the density that can be expected for ice that has been formed under such conditions.

The prediction of the load that can be safely transported and placed upon the ice cover is an important consideration in the use of landings. It depends on the strength of the ice. Since Tabata (1958-60) has shown that density is a major factor that affects the strength of ice, information concerning density would be useful for calculations on the strength of the ice cover.

It is sometimes necessary to keep logs dry in storage. The maximum load in this case depends on the buoyancy of the ice, since there is always a possibility that cracks will allow water to come up if the ice is overloaded. The buoyancy of the ice depends upon its thickness and density. Thickness is generally known or can be controlled. What is required for calculations on critical loads is information on the ice density.

There are two main types of naturally and artificially formed ice: "blue ice", formed from water only, and "snow-ice", from a mixture of water and snow. Studies in Sweden (Ager, 1960) indicate that the content of snow-ice in the naturally formed ice on lakes and rivers is generally quite high, very often one-third or more of the total thickness when the ice cover reaches its maximum thickness during the winter. This snow-ice is usually formed

* This work was done while the author held a post-doctorate fellowship with the Snow and Ice Section, Division of Building Research, National Research Council, Ottawa, Canada, 1960-6i. 
when the load of snow on the ice is heavy enough to cause water to come up through cracks in the cover and wet the snow. A great part of the preparatory work on ice landings will result in the formation of snow-ice also.

Because of the scarcity of information on the density of naturally and artificially formed ice and on how it is influenced by various factors, a study of the subject was undertaken. The observations and results of this study are presented in this paper.

\section{EARLIER INVESTIGATIONS}

Blue ice free of air bubbles has a density of about $0.9^{1} 7 \mathrm{~g} . / \mathrm{cm} .{ }^{3}$ at $0^{\circ} \mathrm{C}$. It often contains air bubbles, however, and there is little information in the literature on their effect. Observations on the density of naturally formed snow-ice in lakes and rivers have been reported as by-products of other investigations. The values reported range from 0.78 to $0.87 \mathrm{~g} . / \mathrm{cm} .^{3}$ (Butkovich, I954, I955). No observations on the density of artificially formed ice on lakes and rivers was found.

The author carried out field studies of an introductory nature in Arvidsjaur in northern Sweden during the winter 1958-59 (Ager, 1960), measuring the density of ice samples by a very simple field method. Each sample was cut into cubes of approximately $20 \mathrm{~cm} \cdot{ }^{3}$ volume, and the displacement of each observed in a $500 \mathrm{~cm} \cdot{ }^{3}$ glass cylinder filled with water at $0^{\circ} \mathrm{C}$. These studies gave values averaging around 0.900 to $0.905 \mathrm{~g} . / \mathrm{cm} .^{3}$ for both naturally and artificially formed snow-ice. There is a possibility that an overestimation of the density by $\mathrm{I}$ to 2 per cent might have occurred because of the technique of measurement.

Measurements by H. M. Sundberg-Falkenmark (personal communication) on naturally formed snow-ice on the lake Storsjön in Sweden during the same winter, gave an average density of $0 \cdot 900 \pm 0 \cdot 004 \mathrm{~g} . / \mathrm{cm} .^{3}$ for 20 samples.

\section{Field Observations and Laboratory Tests During the Winter ig6o-6i}

During the winter 1960-6I samples were taken from naturally and artificially formed ice in the Ottawa and Iroquois Falls areas in Ontario. Observations were also carried out on ice grown in a cold room.

\section{Techniques and accuracy of observations}

All samples, including those taken in the field, were measured in the cold room at $-9.5^{\circ} \mathrm{C}$. A specimen was prepared with a band-saw and weighed; surface pits (cut air bubbles) were then filled with water from an eyedropper; this water froze very quickly. Finally, the volume was measured by observing the change in level of kerosene in a cylindrical container when the specimen was submerged in it.

The volume of the specimen was normally between 60 and $210 \mathrm{~cm} .^{3}$. In order to determine the error of measurement, ten consecutive measurements on weight and volume were carried out on one $200-\mathrm{cm} .{ }^{3}$ and one $70-\mathrm{cm} .{ }^{3}$ piece of clear ice. The mean and standard deviation for the calculated density was found to be $0.9196 \pm 0.0003 \mathrm{~g} . / \mathrm{cm} .^{3}$ and $0.9170 \pm 0.0013 \mathrm{~g} . / \mathrm{cm} .{ }^{3}$ respectively. This error of measurement was considered small enough for the tests carried out; generally, only one measurement was made on each specimen.

Some of the samples were stored up to four months before the density was measured; a check showed that the influence of the length of this storage time on density was insignificant.

\section{Field observations}

Snow-ice samples were obtained in January from McKay Lake near Ottawa and from the Mistango River close to where it empties into Lake Abitibi near Iroquois Falls. In February additional specimens were obtained from Meach Lake, 25 miles (40 km.) north of Ottawa. The snow-ice had been formed by natural flooding. Densities measured are shown in Table I. 
Table I. Densities of Snow Ice from McKay Lake, Meach Lake and Mistango River, Ontario

$\begin{array}{lcccc} & \begin{array}{c}\text { No. of } \\ \text { samples }\end{array} & \begin{array}{c}\text { No. of } \\ \text { specimens }\end{array} & \begin{array}{c}\text { Average } \\ \text { density } \\ \mathrm{g} . / \mathrm{cm} .^{3}\end{array} & \begin{array}{c}\text { Standard } \\ \text { deviation }\end{array} \\ \text { McKay Lake, var. loc. } & 9 & 9 & 0.889 & 0.010 \\ \text { McKay Lake, I loc. } & \mathrm{I} & 7 & 0.870 & 0.009 \\ \text { Meach Lake, var. loc. } & 8 & 8 & 0.892 & 0.004 \\ \text { Mistango River, I loc. } & \mathrm{I} & 2 & 0.900 & -\end{array}$

Individual sample values ranged from $0 \cdot 870$ to $0.902 \mathrm{~g} . / \mathrm{cm} .{ }^{3}$. The note "var. loc." means that the samples were taken from several parts of the lake, "I loc." that only one sample (piece of ice) was taken. The standard deviation for the McKay Lake observations indicates that the variation within one big piece of ice was almost as large as that between specimens taken from various locations on the same lake.

Some snow-ice samples were taken from McKay Lake on 28 March, a day with heavy thaw. The snow-ice layer had a total thickness of I I cm. The upper $5 \mathrm{~cm}$. was very soft and it was possible to disaggregate this ice by hand; the lower layer was more solid. A sample was taken and stored in the cold room at $-9.5^{\circ} \mathrm{C}$. Density was then measured and found to be $0.806 \mathrm{~g} . / \mathrm{cm} .{ }^{3}$ in the soft layer and $0.877 \mathrm{~g} . / \mathrm{cm} .{ }^{3}$ in the hard layer.

Samples were also collected from three ice landings where flooding with pumps had been carried out. The observations are given in Table II. The conditions on the ice landing at Lake Abitibi at the time of flooding were not recorded.

Table II. Origin and Measured Densities of Ice Samples Taken from Artificially Flooded Ice Landings

\begin{tabular}{|c|c|c|c|c|}
\hline Place & $\begin{array}{l}\text { Snow conditions } \\
\text { when flooding }\end{array}$ & $\begin{array}{c}\text { Density } \\
\text { of ice } \\
\mathrm{g} \cdot / \mathrm{cm} .^{3}\end{array}$ & $\begin{array}{l}\text { No. of } \\
\text { samples }\end{array}$ & $\begin{array}{l}\text { Approximate } \\
\text { temperature } \\
\text { after flooding }\end{array}$ \\
\hline Rivière du Sourd & No snow & $0 \cdot 894$ & 1 & Not known \\
\hline Rivière du Sourd & $I$ in. $(2.5 \mathrm{~cm}$.$) new snow$ & $0 \cdot 890$ & 1 & $-10^{\circ} \mathrm{C}$ \\
\hline Rivière du Sourd & No snow & $0 \cdot 909$ & I & $-20^{\circ} \mathrm{C}$ \\
\hline Rivière du Sourd & 2 in. $(5 \mathrm{~cm}$.$) new snow$ & $0 \cdot 894$ & 1 & $-3^{\circ} \mathrm{C}$ \\
\hline Rivière du Sourd & 1 in. $(2.5 \mathrm{~cm}$.$) new snow$ & $0 \cdot 886$ & 1 & $-25^{\circ} \mathrm{C}$ \\
\hline Rivière du Sourd & No snow & $0 \cdot 867$ & 1 & $-12^{\circ} \mathrm{C}$ \\
\hline Mistango River & $\begin{array}{l}8 \text { in. }(20 \mathrm{~cm} .) \text { coarse-grained } \\
\text { snow }\end{array}$ & 0.887 & I & $-25^{\circ} \mathrm{C}$ \\
\hline Lake Abitibi & Not known & $0 \cdot 839$ & 2 & Not known \\
\hline
\end{tabular}

The samples were all collected in January. It is interesting that for the few samples obtained from the Rivière du Sourd site, no significant difference was observed between those prepared by flooding on snow-covered ice and those on bare ice. The thickness of the ice formed during each flooding varied from $3 \cdot 5$ to $6 \cdot 0 \mathrm{~cm}$. The average density of the artificially prepared part of the ice on Rivière du Sourd was $0.890 \mathrm{~g} . / \mathrm{cm} .{ }^{3}$.

Samples were taken of naturally formed blue ice on McKay Lake and on Rivière du Sourd in December after a cold spell that produced about $20 \mathrm{~cm}$. of blue ice on McKay Lake and $25 \mathrm{~cm}$. on Rivière du Sourd. That from McKay Lake was completely free of air bubbles and had a density of $0.918 \mathrm{~g} . / \mathrm{cm} .{ }^{3}$, while the ice from Rivière du Sourd contained longitudinal bubbles of varying size and frequency through the whole sheet. The ice sample from Rivière du Sourd had an average density of $0.915 \mathrm{~g} . / \mathrm{cm} .{ }^{3}$, and the layer containing the greatest amount of bubbles had a density of $0.911 \mathrm{~g} . / \mathrm{cm} .^{3}$. 
Tests in the cold room

A series of tests was carried out in a cold room to discover to what degree different variables might influence the air content of the snow-ice and thus its density. The influence of following variables was observed:

(a) The density of the snow. Under natural conditions snow density is usually between 0.10 to $0.40 \mathrm{~g} . / \mathrm{cm} .{ }^{3}$ and may reach $0.55 \mathrm{~g} . / \mathrm{cm} .{ }^{3}$ when compacted artificially. This range was covered in the tests.

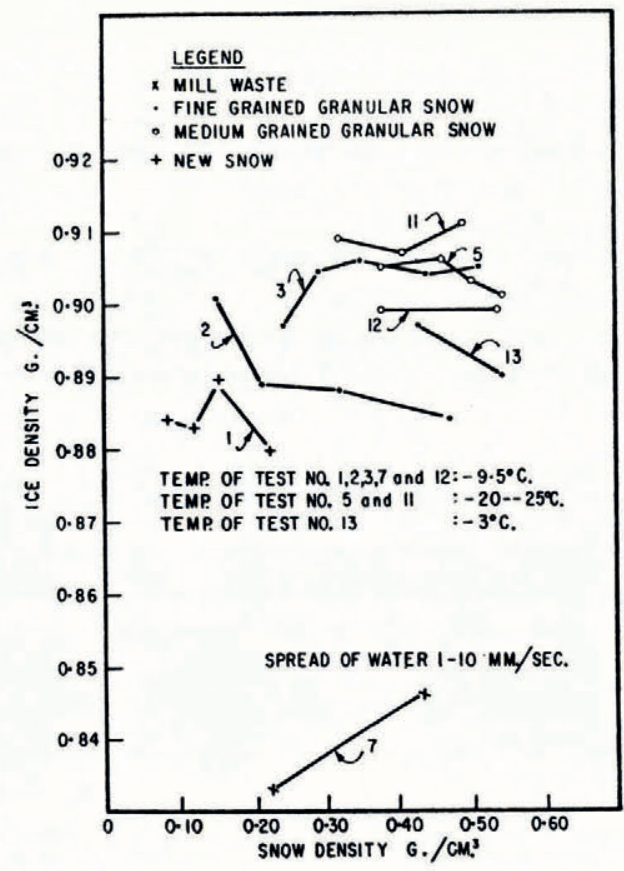

Fig. 1 . The dependence of ice density on initial snow density

(b) The size and shape of the snow particles. Under natural conditions this might range from fine-grained ( $<0.5 \mathrm{~mm}$.) new snow to coarse-grained $(2-5 \mathrm{~mm}$.) depth-hoar snow. This range was covered in the tests. Very fine-grained $(\approx 0 \cdot \mathrm{Imm}$.) waste from an ice-milling machine was used also.

(c) The rate of spread of the water in the snow. In natural flooding this rate is probably less than $\mathrm{I} \mathrm{mm}$./sec. in most cases. When flooding with pumps is carried out the speed generally ranges between 5 and $50 \mathrm{~mm}$./sec. The rates observed in the tests ranged from 0.02 to $34 \mathrm{~mm}$. $/ \mathrm{sec}$.

(d) The rate of freezing of the slush (snow-water mixture). The rate of freezing might vary between $0 \cdot 0 \mathrm{I}$ and ro $\mathrm{mm}$./ hr. in the field. After artificial flooding of a snow cover on top of the ice the freezing rate generally ranges between $\mathrm{I}$ and $5 \mathrm{~mm}$. $/ \mathrm{hr}$. In most of the tests the freezing rate of the slush was 2 to $3 \mathrm{~mm}$./ hr. The highest and lowest values observed were $\mathrm{I}$ and $8 \mathrm{~mm}$. $/ \mathrm{hr}$.

\section{Test procedure}

A plastic cylinder with a height of $86 \mathrm{~mm}$., an inner diameter of $63 \mathrm{~mm}$., and a perforated bottom was filled with snow. The cylinder was then lowered into a tank of water at the same 
speed as the water level rose in the snow until water reached the top of the container, i.e. the surface of the snow. The specimens and the water in the tank were then allowed to freeze from the top. The freezing time was generally between 18 and $24 \mathrm{hr}$. Air temperature in the cold room was approximately $-9 \cdot 5^{\circ} \mathrm{C}$. A few specimens were prepared at other temperatures. The water temperature at the start was between $0^{\circ} \mathrm{C}$. and $+2^{\circ} \mathrm{C}$. A reference specimen of clear water was usually frozen each time. The water used was the local drinking water.

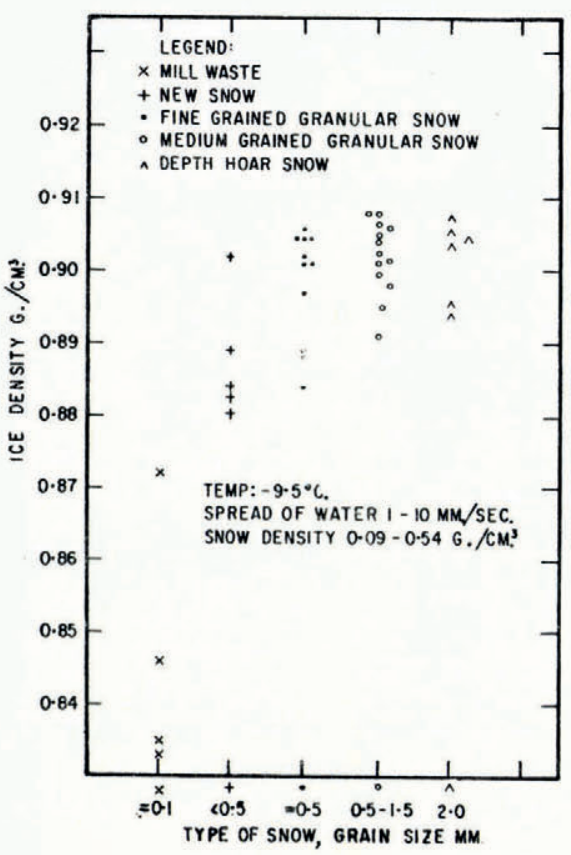

Fig. 2. The dependence of ice density on snow type

A few exceptions to the general test procedure were made:

(a) In order to reach a rate of spread of water in the snow higher than $10 \mathrm{~mm}$. $/ \mathrm{hr}$. a snowfilled sampler was kept vertical and the water was forced through the snow from the top by a hand pump. When the whole specimen was wetted the sampler was immediately immersed in the water in the tank.

(b) In some tests a "base" ice was prepared first in the lower half of the cylinders, then the remaining half was filled with snow. Water $\left(0 \cdot 0\right.$ to $+\mathrm{I} \cdot \mathrm{o}^{\circ} \mathrm{C}$.) was poured on the ice from the top on one side until the water level reached the top of the snow.

\section{Test results}

The test results are plotted in Figures I to 4 for the tests in which the ice could freeze without restriction (no base ice). In some cases the points in the graph are connected with lines; the points connected were obtained from specimens frozen at the same time and under identical conditions, the only factor varied being the one indicated on the graph.

The following conclusions have been drawn from the observations:

(i) A variation in the density of each snow type did not have any marked effect on the density of the ice (Fig. I).

(ii) Grain size had a strong influence for very fine-grained ( $<\mathrm{I} \cdot 0 \mathrm{~mm}$.) snow (Fig. 2). 
The mill waste gave much lower values than all other types of snow tested. Within the range of snow types normally encountered under field conditions (new snow to coarsegrained depth-hoar snow) there was no significant difference in ice density, the values ranging between 0.88 and $0.9 \mathrm{I} \mathrm{g} . / \mathrm{cm} .^{3}$, with a slight trend to lower values for the fine-grained snow.

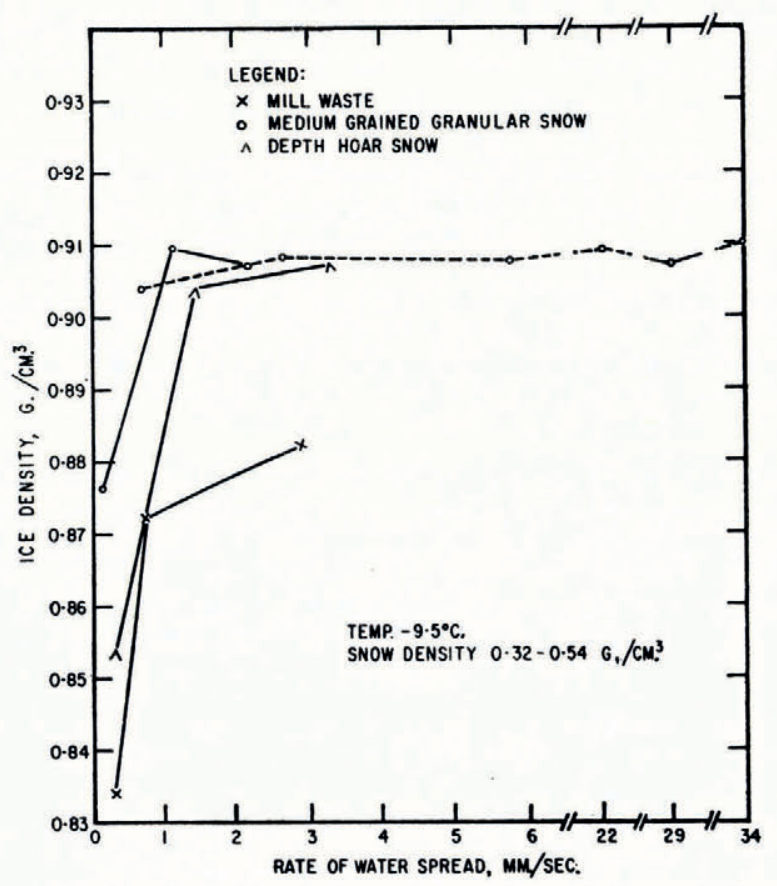

Fig. 3. The dependence of ice density on the rate of spread of water in the snow

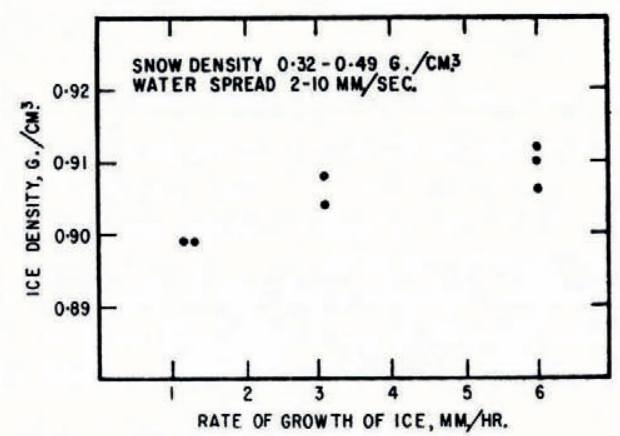

Fig. 4. The dependence of ice density on the rate of growth of the ice

(iii) The rate of spread of water showed a significant influence on the resulting ice density for lower rates, in the range of values encountered in natural flooding (Fig. 3). For rates of spread in the range which occurs when flooding is carried out with pumps, no significant influence was found.

(iv) Within the limits used in the tests, the freezing rate of the slush had a minor influence on resulting ice density, producing slightly lower values at low freezing rates (Fig. 4). 
The clear water specimens used as a check in most of the tests had a mean density of $0.917 \mathrm{~g} . / \mathrm{cm} .^{3}$, with a standard error of $\pm 0.001 \mathrm{~g} . / \mathrm{cm} .^{3}$. Variation in the air content of these specimens could not be related to any of the factors measured.

For the four cases where the specimens were prepared on a base ice, freezing occurred both from the top and from the bottom, most of it from the top. A layer of air bubbles was formed where the interfaces met. In clear water this layer was very pronounced. The density of the clear-water specimens, which were 30 to $40 \mathrm{~mm}$. thick, averaged $0.910 \mathrm{~g} . / \mathrm{cm} .{ }^{3} \mathrm{showing}$ a significant difference from the clear-water specimens prepared according to the standard test procedure. The air layer in the joint between the ice interfaces was far less pronounced in the snow-ice specimens and their density did not differ significantly from the densities obtained for specimens prepared by unrestricted freezing. For granular snow and mill waste one series was carried out on base ice with a variation of the freezing rate from $\mathrm{I}$ to $6 \mathrm{~mm}$. $/ \mathrm{hr}$. No significant influence on the final density was found within this range of rate of freezing.

In all tests reported above, the snow was completely saturated with water, that is the water level was at the snow surface. One test was carried out in which only the bottom of the cylinder was immersed and kept in the water. Results of this test, carried out at $-9.5^{\circ} \mathrm{C}$. air temperature and $0^{\circ} \mathrm{C}$. initial water temperature, are shown in Table III.

Table III. Density of Snow-Ice Made by Capillary Wetring of Snow

\begin{tabular}{|c|c|c|c|}
\hline Description of snow & $\begin{array}{l}\text { Density } \\
\text { of snow } \\
\text { g. } / \mathrm{cm}^{3}{ }^{3}\end{array}$ & $\begin{array}{c}\text { Height of } \\
\text { capillary } \\
\text { layer } \\
\mathrm{mm} .\end{array}$ & $\begin{array}{c}\underset{\text { Density of }}{\text { of }} \\
\mathrm{g} \cdot / \mathrm{cm} .^{3}\end{array}$ \\
\hline Fine-grained $(0.5 \mathrm{~mm}$.) granular snow & $0 \cdot 50$ & 86 & $0 \cdot 879$ \\
\hline Fine-grained $(0.5 \mathrm{~mm}$.$) granular snow$ & $0 \cdot 24$ & $4^{2}$ & Not measurable \\
\hline Fine-grained $(0.5 \mathrm{~mm}$.$) granular snow$ & $0 \cdot 50$ & 86 & $0 \cdot 876$ \\
\hline Fine-grained (o.5 mm.) granular snow & 0.20 & 54 & Not measurable \\
\hline Depth hoar $\left(0.5^{-2} \cdot 0 \mathrm{~mm}.\right)$ & $0 \cdot 54$ & 86 & $0 \cdot 880$ \\
\hline Depth hoar $\left(0.5^{-2} .0 \mathrm{~mm}.\right)$ & 0.28 & $3^{8}$ & Not measurable \\
\hline
\end{tabular}

The low snow density values were obtained by pouring the snow into the cylinders while the high densities were obtained by compacting the snow in 2-cm. layers. The ice prepared from the loose snow samples was very porous and an adequate determination of the density was not considered possible. The samples with compacted snow were wetted to the top (86 mm.) while the water reached $3^{8}$ to $54 \mathrm{~mm}$. above the water surface in the samples with low density.

\section{Classification of SnOw-Ice}

Snow-ice is sometimes classified by eye according to its colour, i.e. dark and bright, and different strength properties are attributed accordingly. It was not possible, however, to find any simple relationship between colour and density in these tests or the tests carried out by the author earlier (Ager, 1960). For example, ice made artificially by compacting and flooding might be bright white, while a dark and transparent snow-ice can be obtained by natural flooding, both types of ice having the same density. In the first mentioned type of ice the air may be contained in many small bubbles and in the second in a few large bubbles.

The author tried a classification system where the frequencies of air-bubbles of different size were described as "abundant", "frequent", "local", "occasional" and "rare", a system which is often used in the description of plant communities. The size of the bubbles was estimated by eye. It was found that the frequency of bubbles of $\mathrm{I} \mathrm{mm}$. size and larger had a significant 
influence on the density of the snow-ice. A classification based on bubble frequency and size may be a better basis for estimating the strength of snow-ice than one based on the colour. The Snow, Ice and Permafrost Research Establishment uses a system based on an estimation of the size and frequency of air bubbles. According to their system all the ice observed in these tests, except the few with a density lower than $0.86 \mathrm{~g} . / \mathrm{cm} .{ }^{3}$, fell within the range of "dense" to "very dense" ice (personal communication from G. B. Frankenstein).

\section{Conclusions}

Field studies reported here and in earlier Swedish investigations indicate that the density of snow-ice formed either naturally or artificially is usually between 0.87 and $0.9 \mathrm{I} \mathrm{gm.} / \mathrm{cm} .{ }^{3}$ and often between 0.88 and $0.90 \mathrm{~g} . / \mathrm{cm} .{ }^{3}{ }^{*}$ These values tend to be larger than those that have been reported in the literature. There is some indication that the density of snow-ice depends on the climate of the region in which it is formed (Butkovich, I954, 1955; personal communication from G. B. Frankenstein).

Observations made under controlled conditions indicate that only for grain sizes less than I mm. did grain size have a significant influence on the density of snow-ice. They showed also that the density decreased with decreasing rate of water spread in the speed range normally encountered under natural flooding conditions, but is quite insensitive to rate of spread in the range normally encountered in artificial flooding operations. The density of the snow and the rate of freezing of the slush had a minor influence. Low density values may be obtained for snow-ice formed by capillary wetting of undisturbed snow with low density.

The observations on blue ice, formed naturally and in the cold room, suggest that density values between 0.90 and $0.92 \mathrm{~g} . / \mathrm{cm} .^{3}$ will probably be the most frequent ones when the ice can freeze without restriction. For the case where water is cast on bare ice in layers a few centimeters thick, both laboratory tests and field observations indicate that values between 0.87 and $0.9 \mathrm{I} \mathrm{g} . / \mathrm{cm} .{ }^{3}$ may be found.

\section{Acknowledgements}

The author wishes to express his gratitude to the National Research Council of Canada, for the award of a post-doctorate fellowship, which made it possible to carry out this investigation. Access to a well equipped cold room has been especially appreciated.

The author is also indebted to Mr. L. W. Gold and Mr. G. P. Williams, for helpful criticism and guidance in preparing this report and to $\mathrm{Mr}$. R. Ducharme for his assistance in measuring densities.

This paper is a contribution from the Division of Building Research, National Research Council of Canada, and is published with the approval of the Director of the Division.

\section{$M S$. received 27 January 1962}

\section{REFERENCES}

Ager, B. H. 1960. Studier över tatheten hos några typer av is. Statens Skogsforskningsinstitut, Avdelingen för Arbetslära, Serien Rapporter, Nr. 9.

Butkovich, T. R. 1954. Ultimate strength of ice. U.S. Snow, Ice and Permafrost Research Establishment. Research Paper II.

Butkovich, T. R. 1955. Crushing strength of lake ice. U.S. Snow, Ice and Permafrost Research Establishment. Research Paper 15.

Tabata, T. 1958-60. Studies on mechanical properties of sea ice. II-V. Low Temperature Science, Ser. A, Vol. I 7 , p. 147-66; Vol. 18, p. I 16-48; Vol. 19, p. 187-201.

* Further confirmation of this result was received by measurements in Sweden during the winters 1959-60 and $1960-6 \mathrm{I}$, sponsored by Sveriges Meteorologiska och Hydrologiska Institut (personal communication from H. M. Sundberg-Falkenmark). 